Research Article

\title{
Wound healing property of paroxetine in immunosuppressed albino rats
}

\author{
Dwajani S*, Ranjana Gurumurthy
}

Department of Pharmacology, St. John's Medical College and Hospital, Bangalore, Karnataka, India

Received: 24 September 2013 Accepted: 8 October 2013

\section{*Correspondence to: \\ Dr. Dwajani S, \\ Email: dwajani@gmail.com}

(C) 2013 Dwajani S et al. This is an open-access article distributed under the terms of the Creative Commons Attribution Non-Commercial License, which permits unrestricted non-commercial use, distribution, and reproduction in any medium, provided the original work is properly cited.

\begin{abstract}
Background: The objectives of this study were to evaluate the wound healing activity of Paroxetine in different wound models in wistar rats and to study its effects on dexamethasone suppressed wound healing.

Methods: For assessment of wound healing activity, excision and incision wound models were used. Group I was assigned as control, orally, Group II received Paroxetine, i.p, Group III received Dexamethasone intramuscularly (i.m) and Group IV received Dexamethasone i.m and Paroxetine, i.p. Parameters observed were epithelization and wound contraction of excision model and breaking strength of incision wound model.

Results: In incision model, it was noted that the breaking strength was not significantly increased in paroxetine treated group when compared to control group. Paroxetine hastened the period of epithelization and the effect of dexamethasone was reversed by paroxetine in incision and excision models Conclusion: It is concluded that Paroxetine could be an effective agent for healing wounds in immunocompromised patients.
\end{abstract}

Keywords: Paroxetine, Dexamethasone, Excision, Incision, Rats

\section{INTRODUCTION}

Wound is an injury to the body either as form violence, accident or surgery, which typically involves laceration or breaking of a membrane as the skin and usually damage to underlying tissues. ${ }^{1}$ In pathology, it specifically refers to a sharp injury which damages the dermis of the skin. ${ }^{2}$ It is a disruption in the normal anatomical structure and function of living tissue that can be used by physical, chemical, microbiological or immunological injury. ${ }^{3}$

Wound healing is essentially a survival mechanism and represents an attempt to maintain normal anatomical structure and function. When healing takes place in a direction away from its normal course, it may result in non healing, under healing or over healing. Therefore attempts have been made to accelerate wound healing either when it is progressing normally ${ }^{3}$ or when it is suppressed by corticosteroids, ${ }^{4}$ anti neoplastic ${ }^{5}$ and non steroidal anti-inflammatory agents. ${ }^{6}$ Treatment is aimed at either shortening the time required for healing or minimizing the undesired consequences. ${ }^{7}$

Selective Serotonin Reuptake inhibitors [SSRI's] are the first line agents for the treatment of depression. ${ }^{8}$ SSRI's are also used in the treatment of post traumatic stress, obsessive compulsive disorder and social phobia. ${ }^{8,9}$ The use of topical application of SSRI's is proven to be promising for wound repair in high risk patients, especially with diabetes mellitus, venous insufficiency, obesity and other vascular disorder. ${ }^{10}$ Fluoxetine significantly improves healing of cutaneous wounds in stressed and to lesser extent in non stressed animals. ${ }^{11}$

Since these are preliminary studies and as rats are easy to handle. Easily available, easy to subject for testing and their nutrition resembles that of man, they are used for the present study. Hence the present study was designed and it was decided to determine the wound healing activity of Paroxetine and to study its effect on 
Dexamethasone suppressed wound healing in various animal models in wistar rats.

\section{METHODS}

\section{Process of Wound Healing}

Wounds may be caused by ${ }^{12}$

1. Traumatic excision - accidental or surgical

2. Physical, chemical or microbiological agents

3. Ischemia which leads to infraction

Wounds can be classified into two general categories ${ }^{13}$

a. Cut wounds, which normally proceed through an orderly and timely reparative process that results in sustained restoration of anatomical and functional integrity.

b. Chronic wounds, which fail to proceed through an orderly and timely reparative process to produce anatomical and functional integrity of proceed the repair process without establishing a sustained anatomical and functional sheath.

The wound healing refers to the process of replacement of destroyed tissue by living tissue. Wound healing is a dynamic interactive process that begins at the time of wounding. There are two aspects of wound healing, regeneration and repair.

$\checkmark$ Regeneration: is the process whereby lost specialized tissue is replaced by proliferation of surrounding specialized cells.

$\checkmark$ Repair: is the replacement of the lost tissues by granulation tissue which matures to form a scar.

Three distinct biological mechanisms are involved in wound healing. They are:

a. Epithelization - it is process whereby keratinocytes migrate and then divide to resurface partial thickness loss of skin mucosa.

b. Contraction - it is the mechanism whereby there is a mechanical reduction in the size of the wound

c. Connective tissue matrix deposition - it is the process whereby fibroblasts are recruited to the site of injury and produce a new connective tissue matrix. The cross lined collagen and its organization in the connective tissue formed in the process provide the strength and integrity to all tissues.

The various processes of wound healing can be grouped into a sequence of three time limited processes. ${ }^{14}$

- Lag Phase - this is the immediate homeostasis or inflammation phase of wound healing. It reflects the time required to many cellular elements that are activated during the early repair. ${ }^{15}$
- Proliferative Phase - there is formation of granulation tissue in the wound and synthesis of collagen and mucopolysaccharides. There is increase in mechanical strength of wound.

- $\quad$ Phase of remodelling - the number of cells in the wound decreases. There is extensive remodelling of wound collagen and further increase in mechanical strength of wound.

Hence, to monitor the various phases of wound healing, it is necessary to have different wound models. In the present study, the wound healing activity has been studied in 2 different models - excision and incision.

Ethical Clearance - Institutional Ethical clearance was obtained.

Animals: Twelve week old healthy wistar rats weighing 150-200g of either sex, bred locally in the animal house were selected for the study. They were housed under controlled conditions of temperature $\left(23 \pm 20^{\circ} \mathrm{C}\right)$, humidity $(50 \pm 5 \%)$ and $10-14$ hours of light and dark cycles. The animals were housed individually in polypropylene cages containing sterile paddy husk bedding and free access to food and water ad libitum. Animals were grouped into 4 of six animals each $(n=24$ for each models. Therefore for 2 different models $n=48$ ).

\section{Study design}

The animals were randomly allocated into four groups of six animals each.

Group I: Control, received 2ml Distilled water.

Group II: received Paroxetine 10mg $/ \mathrm{kg},{ }^{16}$ intraperitoneally

Group III: received Dexamethasone $0.17 \mathrm{mg} / \mathrm{kg},{ }^{17}$ intramuscularly

Group IV: received Dexamethasone i.m + Paroxetine i.p

\section{Dosing schedule}

Paroxetine was administered intraperitoneally, once daily from day 0 to the day of complete healing or the 10th post operative day, whichever occurred earlier, in the wound healing model. Dexamethasone was given i.m on alternative days from day 0 to the day of complete healing or 10th postoperative day.

\section{Wound Model}

For assessment of wound healing activity, excision and incision wound model were used. All wounding procedures were carried out under ketamine anaesthesia i.m $100 \mathrm{mg} / \mathrm{kg}$. In the present study no animals showed visible signs of infection. 
Incision wound model: Two long paravertebral straight incisions of $6 \mathrm{~cm}$ each were made $1 \mathrm{~cm}$ lateral to the vertebral column on the either side of the depilated back of the animal, cutting through the entire thickness of the skin. ${ }^{18}$ The wounds were closed with the sutures $1 \mathrm{~cm}$ apart with No.4 black silk thread and straight needle. ${ }^{19}$ The sutures were removed on the 7 th post wounding day and breaking strength was measured on the 10th day by continuous constant water flow technique of Lee. ${ }^{6}$

Excision wound model: An excision wound was made by cutting away a circular area of full thickness of skin measuring $500 \mathrm{~mm}^{2}$ on the depilated back of the rat, in the dorsal interscapular region, $5 \mathrm{~cm}$ away from the ears. ${ }^{20}$ Period of epithelization was noted as the number of days after wound healing required for the eschar to fall off leaving no raw wound behind. Wound contraction rate was monitored by planimetric measurement of wound area on alternate days. This was done by tracing the wound area on a graph paper. Reduction in the wound size was expressed as percentage of original wound size. ${ }^{21}$

\section{Statistical analysis}

The results were analyzed by One way Analysis of Variance (ANOVA) followed by using SPSS computer package version 16 .

\section{RESULTS}

Incision wound model: The mean breaking strength in the Group 1 was $188.33 \pm 13.72 \mathrm{~g}$ and it was increased to $210.19 \pm 14.11 \mathrm{~g}$ in the Group 2. In Group 3, the mean breaking strength was reduced to $111 \pm 10.95 \mathrm{~g}$ compared to group 1 and 2. The Group 4 had 172.5 $\pm 13.13 \mathrm{~g}$ compared which was increased when compared to Group 3 [Table 1].

Excision wound model: The percentage of wound contraction in the group 1 was $277 \pm 16.64$, 168.66 \pm 12.98 , $72.83 \pm 8.53$ and $15.57 \pm 3.93$ as measured on the $4^{\text {th }}, 8^{\text {th }}$, $12^{\text {th }}$ and $16^{\text {th }}$ day respectively. The wound contraction rate was altered in group 2 as compared to group 1. The difference was also observed in group 4 in comparison to group 3. The mean period of epithelization in the group 1 was $23.66 \pm 4.86$ days. The rate of wound contraction was almost similar when compared between group 2 and group 4 [Figure 1]. There was no significant alteration in animals treated with both Dexamethasone and Control group [Table 2].

\section{Table 1: Effect of drugs on incision wound} parameters.

\begin{tabular}{|lll|}
\hline Drugs & $\begin{array}{l}\text { Dose and } \\
\text { Route }\end{array}$ & $\begin{array}{l}\text { Breaking } \\
\text { Strength (g) } \\
\text { Mean } \pm \text { SEM }\end{array}$ \\
\hline Distilled Water & $2 \mathrm{ml}$ oral & $188.33 \pm 13.72$ \\
\hline Paroxetine & $10 \mathrm{mg} / \mathrm{kg}$ i.p & $210.19 \pm 14.11$ \\
\hline Dexamethasone & $0.17 \mathrm{mg} / \mathrm{kg}$ i.m & $111 \pm 10.95$ \\
\hline $\begin{array}{l}\text { Dexamethasone }+ \\
\text { Paroxetine }\end{array}$ & $\begin{array}{l}0.17 \mathrm{mg} / \mathrm{kg} \mathrm{i.m} \\
+10 \mathrm{mg} / \mathrm{kg} \mathrm{i.p}\end{array}$ & $172.5 \pm 13.13 \mathrm{~g}$ \\
\hline $\begin{array}{l}\text { One way ANOVA } \\
\text { (df=3) }\end{array}$ & $\begin{array}{l}\mathrm{F}=6.80 \\
\mathrm{P}<0.005\end{array}$ & -------------- \\
\hline
\end{tabular}

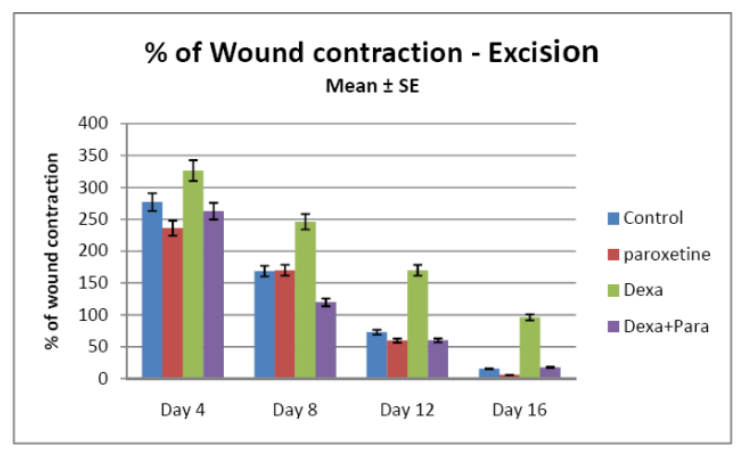

Figure 1: Percentage of wound contraction - excision.

Table 2: Effect of drugs on excision wound parameters.

\begin{tabular}{|c|c|c|c|c|c|c|}
\hline \multirow[t]{2}{*}{ Drugs } & \multirow[t]{2}{*}{ Dose and Route } & \multicolumn{4}{|c|}{$\begin{array}{l}\text { Period of Wound } \\
\text { Contraction ( days) Mean } \pm \text { SE }\end{array}$} & \multirow[t]{2}{*}{$\begin{array}{l}\text { Period of } \\
\text { Epithelization } \\
\text { (Days) Mean } \pm \text { SE }\end{array}$} \\
\hline & & 4 & 8 & 12 & 16 & \\
\hline Distilled Water & $2 \mathrm{ml}$ oral & $277 \pm 16.64$ & $168.66 \pm 12.98$ & $72.83 \pm 8.50$ & $15.5 \pm 3.93$ & $23.66 \pm 4.86$ \\
\hline Paroxetine & $10 \mathrm{mg} / \mathrm{kg}$ i.p & $236.66 \pm 15.38$ & $170.16 \pm 13.04$ & $59.66 \pm 7.72$ & $6.0 \pm 2.44$ & $10.5 \pm 3.24$ \\
\hline Dexamethasone & $0.17 \mathrm{mg} / \mathrm{kg} \mathrm{i.m}$ & $326.16 \pm 18.06$ & $246.00 \pm 15.68$ & $170 \pm 13.03$ & $96.16 \pm 9.8$ & $25.66 \pm 5.06$ \\
\hline Dexamethasone + & $0.17 \mathrm{mg} / \mathrm{kg}$ i.m & $262.83 \pm 16.21$ & $119.66 \pm 10.93$ & $60 \pm 7.74$ & $17.66 \pm 4.20$ & $11 \pm 3.31$ \\
\hline Paroxetine & $10 \mathrm{mg} / \mathrm{kg}$ i.p & & & & & \\
\hline One way ANOVA & $\mathrm{F}$ & $\cdots$ & $\ldots \ldots$ & $\cdots \cdots$ & $\cdots$ & 71.09 \\
\hline $\mathrm{df}=3$ & $\mathrm{P}$ & $\ldots$ & $\ldots \ldots$ & $\ldots$. & $\ldots$ & $<0.005$ \\
\hline
\end{tabular}




\section{DISCUSSION}

Granulation collagen maturation and scar formation are some of many phases of wound healing which run concurrently but independent of each other. The use of single model is inadequate and no reference standard exists that can collectively represent the various phases of wound healing. Among three different models we have chosen two models in our study to assess the effect of paroxetine on wound healing.

Wound contraction is the process of mobilizing healthy skin surrounding the wound to cover the denuded area. This centripetal movement of wound margin is believed to be due to the activity of myofibroblasts. ${ }^{22}$ Since paroxetine to certain extent enhances wound contraction it would have either enhanced contractile property of myofibroblasts or increase the number of myofibroblasts recruited into the wound area.

In the present study, the breaking strength of the incision wound was not significantly increased in the paroxetine treated group as compared to control. Dexamethasone inhibits wound contraction, granulation tissue and collagen formation. ${ }^{4}$ This is the cause of suppressed wound healing in the Dexamethasone treated group in all wound models. Paroxetine hasten the period of epithelization and the effect of Dexamethasone was reversed by Paroxetine in incision and excision models, where the breaking strength of Dexamethasone + paroxetine treated was higher than that of the group treated with Dexamethasone alone.

Oxidative stress has been implicated in a variety of degenerative processes and diseases including wound healing. ${ }^{23}$ This could contribute to its pro-healing effects. Paroxetine also reversed the suppression of wound healing by Dexamethasone to an extent. The enhanced wound contraction effect and epithelization by Paroxetine could possibly be made used clinically for healing wounds in immunocompromised patients and in patients on long term steroid therapy. Patients already receiving paroxetine and having wound may reduce the need of other drugs.

Our data demonstrates that paroxetine may be capable of promoting wound healing activity. However, it needs further evaluation in clinical settings before consideration for the treatment of wounds.

Funding: No funding sources Conflict of interest: None declared

Ethical approval: The study was approved by the Institutional Animal Ethical Committee

\section{REFERENCES}

1. http://www.merriam-webster.com/dictionary/wound accessed on 10th July 2013.
2. http://en.wikipedia.org/wiki/Wound accessed on 10th July 2013.

3. Brown GL, Curtsinger LT, White M, Mitchell RO, Pietsch J, Nordquist R et al. Accelaration of tensile strength of incisions treated with EGF and TGF $\beta$. Ann Surg. 1998a; 208: 778-792.

4. Ehrlich HP, Hunt TK. Effect of cortisone and vitamin A on wound healing. Ann Surg. 1968; 167:324-328.

5. Raju SS, Kulkarni DR. Vitamin A reverses the wound healing suppressant effect of cyclophosphamide. Ind J Pharmacol. 1986;18:154157.

6. Lee KH. Studies on mechanism of action of salicylates III, effect of vitamin A on wound healing retardation of aspirin. J Pharma Sci. 1968a;57:12381240 .

7. Myers KA, Marshall RE, Friedin J. Principles of pathology in surgery. Blackwell scientific Publications. 1980;58-62.

8. David EG, Armen HT, Ehrin J, Armstrong, April WM. Principles of pharmacology, the pathophysiologic basics of drug therapy. Second Edition. Lippioncott Williams and Wilking. 2008; 216.

9. Grahame DG, Aronson JK. Clinical Pharmacology and drig therapy. Third edition. Oxford University press.2002;490.

10. Alex Malinin, Benjamin O, Victor Serebruany. Treatment with selective serotonin reuptake inhibitors for enhancing wound healing. Medical hypothesis. 2004;63:103-109.

11. Farahani, Ramani MZ, Sadr Katayoun et.al. Fluoxetine enhances cutaneous wound healing in chemically stressed in wistar rats. Advances in skin and wound care. 2007;20(3):157-165.

12. Walter JB, Israel CT. Connective tissue: its normal structure and effects of disease. Walter and Isreal general pathology. Seventh edition. Chruchill Livingstone. 1996;103-16.

13. Cophen IK, Diegelmann RF, Crossland MC, Schwatz SI, Shires GT, Spencer FC, Husser WC. Wound care and wound healing.. Principles of surgery. Sixth edition. Mc Graw hill INC. 1994;279304.

14. Iocono JA, Ehrlich HP, Leaper DJ, Harding KG. The biology of healing. Wounds biology and management. Oxford (UK). Oxford university press. 1998;11.

15. Shanbhag T, Shenoy S, et al. Wound healing profile of Tinospora Cardiofolia. Indian Drugs.2005;42:217-21.

16. Kesim M, Duman EN, et.al. The different roles of $5 \mathrm{HT}_{2}$ and $5 \mathrm{HT}_{3}$ receptors on antinociceptive effect of paroxetine in chemical stimuli in mice. $\mathbf{J}$ Pharamcol Sci. 2005;97(1):61-6.

17. Dwajani S, Tara VS. Michelica Champaca: Wound healing activity in immunosuppressed rats. Internet Journal of Alternative Medicine. 2009;7(2). 
18. Ehrlich HP, Hunt TK. Effect of cortisone and anabolic steroids on tensile strength of healing wounds. Ann surg.1969;170:203-6.

19. Lee KH, Tang TG. Mechanism of action of retinyl compounds on wound healing II. Effect of active retinyl derivatives on granuloma formation. J Pharma Sci. 1970;59:1195-97.

20. Morton JP, Malone MH. Evaluation of vulnerary activity by an open wound procedure in rats. Arch Int Pharmacodyn. 1972;176:117-226.

21. Bairy KL, Rao CM. Wound healing profile of Ginkgo biloba. J Natural Remedies. 2001;1:25-7.
22. Shanbhag Tara V, Sharma C, Adiga S, Bairy KL, Shenoy S, Shenoy G. Wound healing activity of alcoholic extract of Kaempferia Galanga in wistar rats. Indian $\mathbf{J}$ of Physiol and Pharmacol. 2006;50(4):384-90.

23. Maiere CM, Chan PH. Role of superoxide dismutase in oxidative damage and neurodegenerative disorders. Neuroscientist. 2002; 8: 323-324.

doi:10.5455/2319-2003.ijbcp20131219

Cite this article as: Dwajani S, Ranjana G. Wound healing property of paroxetine in immunosuppressed albino rats. Int J Basic Clin Pharmacol 2013;2:772-6. 